\title{
Modification of AISi9CuMnNi Alloy by Antimony and Heat Treatment and Their Influence on Tool Wear after Turning
}

Natasa Naprstkova ${ }^{1}$, Jaromir Cais ${ }^{1}$, Manuela Ingaldi ${ }^{2}$

${ }^{1}$ Faculty of Production Technology and Management, J. E. Purkyne University in Usti nad Labem. Pasteurova 1, 40096 Usti nad Labem.Czech Republic.E-mail: naprstkova@fvtm.ujep.cz; cais@fvtm.ujep.cz,

2Faculty of Management of Czestochowa University of Technology, ul. Armii Krajowej 19 B, 42-200 Czestochowa, Poland. E-mail: manuela@gazeta.pl

Modification alloy is an important part of the metallurgical process, and this also applies, of course, for aluminum alloys, particularly for Al-Si (silumins). As a modification of the material we can use the modification using the selected element or heat treatment of alloys, or a combination of both processes. One of the elements that it is possible to modify the alloy of Al-Si used is antimony (Sb). The paper examines the possible effect of the modification that element and heat treatment on the final tool wear after machining of the alloy AlSi9CuMnNi. In the experiments were made three castings from the alloy AlSi9CuMnNi without modification, three castings with the modification and without heat treatment, three castings with modification and without heat treatment, and three castings with modification and heat treatment too. These all castings were machining by turning with the same cutting conditions and next the tool wear of using inserts was analyzed. The described experiments and analysis are part of extensive research, focusing on a Faculty of Production Technology and Management, J. E. Purkyne University in Usti nad Labem.

Keywords: alloy, aluminium, modification, antimony, heat treatment, wear, machining

\section{Acknowledgement}

Authors are grateful for the support of grant SGS 2014 UJEP and of grant OP 2.2 No. CZ.1.07/2.2.00/28.0296.

\section{References}

[1] BOLIBRUCHOVA, D., TILLOVÁ, E. (2005). Zlievarenske zliatiny Al-Si. ZU v Ziline, EDIS, Zilina, Slovak Republic.

[2] LIPINSKI, T. (2011). Microstructure and Mechanical Properties of the AlSi13Mg1CuNi Alloy with Ecological Modifier. In: Manufacturing Technology, Vol. 11, No. 1, pp. 40-44, FPTM JEPU, Usti nad Labem, Czech Republic.

[3] ROUČKA, J. (2004). Metalurgie neželezných slitin. 148 p., CERM,. Brno, Czech Republic.

[4] MICHALCOVA, A., VOJTECH, D. (2012). Structure of rapidly solidified aluminium alloys. In Manufacturing Technology. Vol. 12, No. 13, pp. 166-169, FPTM JEPU, Ústí nad Labem, Czech Republic.

[5] MICHNA, S., LUKAC, I., OCENASEK, V., KORENY, R., DRAPALA, J., SCHNEIDER, H., MISKUFOVA, A. and coll. (2005). Encyklopedie hliníku. Adin, Prešov, Slovak Republic.

[6] MICHNA, S., KUSMIERCZAK, S. (2008). Technologie a zpracovani hlinikovych materialu. JEPU, Ustí nad Labem, Czech Republic.

[7] NAPRSTKOVA, N. (2012). Vliv ockovani slitiny AlSi7Mg0,3 ockovadlem AlTi5B1 na opotrebeni nastroje pri jejim obrabení. In: Strojirenska technologie. Vol. 17, No. 5,6, pp. 330-338, FPTM JEPU, Usti nad Labem, Czech Republic.

[8] BILIK, O., MADL, J. (2001). Trvanlivost britu a provozni spolehlivost obrabeciho nastroje. Knihovnicka Strojirenske technologie, sv. 1., 78 p., FPTM, JEPU, Ústí nad Labem, Czech Republic.

[9] CZAN, A., STANCEKOVA, D., DURECH, L., STEKLAC, D., MARTIKAN, J. (2006). Zaklady opotrebenia pri suchom tvrdom sustruzení. In: Nastroje 2006 - ITC 2006, 5. - 6. september 2006, Zlin, Czech Republic.

[10]DUGIN, A., POPOV, A. (2012). Effect of the cutting tool wear on the ploughing force value. In: Strojirenska technologie. Vol. 17, No. 1,2, pp. 19-23, FPTM JEPU, Usti nad Labem, Czech Republic.

[11]DUGIN, A., POPOV, A. (2013). Increasing the accuracy of the effect of processing material and cutting tool wear on the ploughingforce values. In: Manufacturing Technology, Vol. 13, No. 2, pp. 169-173, FPTM JEPU, Usti nad Labem, Czech Republic.

[12] KOCMAN, K. (2011). Technologicke procesy obrabeni. CERM, Brno, Czech Republic. 
[13]KALINCOVA, D. (2010). Skusanie mechanických vlastnosti materialov - prehlad meracich metod a zariadeni. In: proceedings Zvysovanie efektivnosti vzdelavacieho procesu prostrednictvom inovacnych prostriedkov, KEGA 3/6370/08., pp. 13-26, TU vo Zvolene, Zvolen, Slovak Republic.

[14]MADL, J., KOUT, V., RAZEK, V., STRANSKY, R., DUFEK, V. (2004). Metoda pro simulaci zkousek opotrebeni slinutych karbidu. In: Strojirenska technologie. Vol. 9, No. 1, pp. 28-32, FPTM JEPU, Usti nad Labem, Czech Republic.

[15]ISO 3685 (1993) Tool-life testing with single-point turning tools.

[16] MADL. J. (2012). Surface properties in Precise and Hard Machining.In: Manufacturing Technology, Vol. 12, No. 13, pp. 158-166, FPTM JEPU, Usti nad Labem, Czech Republic.

[17]SUCHANEK, D., DUSAK, K. (2011). Impact of cutting conditions on tool wear. In: Strojirenska technologie, Vol. 16, No. 5, pp. 33-37, FPTM JEPU, Usti nad Labem, Czech Republic.

[18]SEBELOVÁ, E., CHLADIL, J. (2013). Tool wear and Machinability of Wood-based Material During Machining Process. In: Manufacturing Technology. Vol. 13, No. 2, pp. 231-236, FPTM JEPU, Usti nad Labem, Czech Republic.

[19] VALICEK, J., RUSNAK, J., MULLER, M., HRABE, P., KADNAR, M., HLOCH, S., KUSNEROVA, M. (2008). Geometricke aspekty drsnosti povrchu klasických a netradicních technologii. In: Jemna mechanika a optika, Vol. 53, No. 9, p. 249-253, Praha, Czech Republic.

[20]OSICKA, K. (2009). Prumerna aritmeticka uchylka drsnosti povrchu - statisticke vyhodnoceni plochy. In: Strojirenska technologie. Vol. 14, No. 1, p. 30-33, FPTM JEPU, Usti nad Labem, Czech Republic. 